\title{
Ozone Flux Measurement and Modelling on Leaf/Shoot and Canopy Scale
}

\author{
Ludger Grünhage ${ }^{1^{*}}$, Giacomo Gerosa ${ }^{2}$ \\ ${ }^{1}$ Department of Plant Ecology, University of Giessen \\ Heinrich-Buff-Ring 26-32, 35392 Giessen, Germany \\ ${ }^{2}$ Dipartimento di Matematica e Fisica, Università Cattolica del Sacro Cuore \\ Via Musei 41, 25121 Brescia, Italy
}

Received: 8 January 2008. Accepted 6 February 2008.

\begin{abstract}
The quantitative study of the ozone effects on agricultural and forest vegetation requires the knowledge of the pollutant dose absorbed by plants via leaf stomata, i.e. the stomatal flux. Nevertheless, the toxicologically effective dose can differ from the stomatal flux because a pool of scavenging and detoxification processes reduce the amount of pollutant responsible of the expression of the harmful effects. The measurement of the stomatal flux is not immediate and the quantification of the effective dose is still troublesome.

The paper examines the conceptual aspects of ozone flux measurement and modelling in agricultural and ecological research. The ozone flux paradigm is conceptualized into a toxicological frame and faced at two different scales: leaf/shoot and canopy scales. Leaf and shoot scale flux measurements require gas-exchange enclosure techniques, while canopy scale flux measurements need a micrometeorological approach including techniques such as eddy covariance and the aerodynamical gradient. At both scales, not all the measured ozone flux is stomatal flux. In fact, a not negligible amount of ozone is destroyed on external plant surfaces, like leaf cuticles, or by gas phase reaction with biogenic volatile compounds. The stomatal portion of flux can be calculated from concurrent measurements of water vapour fluxes at both scales. Canopy level flux measurements require very fast sensors and the fulfilment of many conditions to ensure that the measurements made above the canopy really reflect the canopy fluxes (constant flux hypothesis). Again, adjustments are necessary in order to correct for air density fluctuations and sensor-surface alignment break. As far as regards flux modelling, at leaf level the stomatal flux is simply obtained by multiplying the ozone concentration on the leaf with the stomatal conductance predicted by means of physiological models fed by meteorological parameter. At canopy level the stomatal flux is calculated by SVAT models often based on the energy balance of the soil-vegetation-atmosphere system and on the big-leaf concept. This latter assumes the canopy as equivalent to a single leaf having a leaf area equal to the total area of all the plant's leaves and lying at a certain height above the ground. The complexity of SVAT models ranges from one-dimensional to three-dimensional models. The most used are one-dimensional models in single-layer, dual-source or multi-layer version. The main uncertainties in flux modelling are currently associated to the estimation of the non-stomatal flux component and to the up-scaling process from leaf to canopy and stand level. For the latter a separate representation of sunlit and shaded leaves is recommended.
\end{abstract}

Key-words: ozone, flux measurement, flux modelling, flux-response relationships.

\section{Introduction}

Tropospheric ozone $\left(\mathrm{O}_{3}\right)$ is an all pervasive air pollutant, the human- and phytotoxicity potential of which was emphasized by the German chemist Christian Friedrich Schönbein in his book on ozone already in 1844 . He wrote: "As well as ozone can cause a catarrh, ozone can disorganize a sensitive blossom" (translation; Schönbein,
1844). During the last $100-150$ years background tropospheric $\mathrm{O}_{3}$ concentration increase by a factor up to five (e.g. Marenco et al., 1994) and will increase further on (Midgley et al., 2003; Dentener et al., 2005), from current day annual average background concentrations over the mid-latitudes of the Northern Hemisphere of 20-45 ppb to 42-84 ppb by the year 2100 (Vingarzan, 2004).

\footnotetext{
* Corresponding Author: Tel.: +49 64199 35314; Fax: +49 64199 19907. E-mail address: Ludger.Gruenhage@bot2.bio.unigiessen.de
} 
As a consequence of the discussions about the reasons of the so-called "Neuartige Waldschäden" (forest dieback), since mid 1980s ground-level ozone and its impact on human health and vegetation have increasingly come into focus within the UNECE (United Nations Economic Commission for Europe) and the European Union (EU). The description of the scientific steps for upgrading the concept of "doseresponse" to estimate the risk e.g. to crops from $\mathrm{O}_{3}$ exposure is necessary to well understand the most appropriate approach. A first European workshop on critical levels for $\mathrm{O}_{3}$ to protect vegetation was held 1988 in Bad Harzburg, Germany, (UNECE, 1988), followed by a second one 1992 in Egham, UK (Ashmore and Wilson, 1992). While the 1988 long-term critical level for $\mathrm{O}_{3}$ was defined as a 7-h mean of $25 \mathrm{ppb}$ over the vegetation/growing period, at the Egham workshop a change to an Accumulated expo-

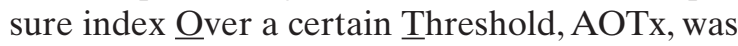
recommended, assuming that plants have adapted to low, pre-industrial, naturally occurring $\mathrm{O}_{3}$ concentrations (Paoletti and Manning, 2007). At the UNECE workshops in Bern, Switzerland, 1993 and Kuopio, Finland, 1996 critical levels for $\mathrm{O}_{3}$ to protect crops, semi-natural vegetation and forest trees using an AOT40 exposure index were defined (Fuhrer and Achermann, 1994; Kärenlampi and Skärby, 1996). This indices are the basis for the current European Convention on Long-Range Transboundary Air Pollution to Abate Acidification, Eutrophication and Ground-Level O 3 (UNECE, 1999) and the European Directive on Ground-level $\mathrm{O}_{3}$ (EU, 2002). Paoletti and Manning (2007) mentioned the following five main reasons why the current AOTx-based standards are inadequate and not worked well: (1) inadequacy of the scientific background, (2) insufficient database for the derivation of AOTx-based standards, (3) insufficient database to select the effect to be evaluated in the field, (4) inappropriate grouping into categories, and (5) no field validation.

One of the basic rules of toxicology is that dose-response relationships can be only established if the effective dose (flux) or at least the absorbed dose (flux) of the stressor is known (Dämmgen et al., 1993; Dämmgen and Grünhage, 1998). The flux approach was introduced into the UNECE critical level community at the workshops 1993 in Bern and 1996 in Kuopio for the first time (Grünhage and Jäger, 1994a, b; Grünhage and Jäger, 1996). Due to the abovementioned uncertainties of the exposure-based critical levels, at the UNECE workshop in Gerzensee, Switzerland, 1999 it was decided to develop a flux-based approach to protect vegetation against the negative effects of $\mathrm{O}_{3}$ (Fuhrer and Achermann, 1999). Cumulative stomatal flux-based critical levels were set for agricultural crops and provisionally for sensitive forest trees at the UNECE workshop in Gothenburg, Sweden, 2002 (Karlsson et al., 2003) and reviewed at a workshop in Obergurgl, Austria, 2005 (Wieser and Tausz, 2006). These critical levels based on flux estimates for the uppermost leaf level that is directly exposed to solar radiation (UNECE, 2007). As recently summarized by Paoletti and Manning (2007) the scientific basis of the flux-based critical levels is appropriate, even if major knowledge gaps for a mechanistic understanding still exist. Additionally, the database for the derivation of the current flux-based $\mathrm{O}_{3}$ standards is inappropriate and the currently available flux-response relationships are not validated in the field. Therefore, it was decided in Obergurgl, that estimation of risk of damage at European scale have to be based on flux-based methods for generic crop and generic tree species. General functions for wheat and potato are available, but their application for the assessment of local risk presents greater uncertainties and the use of local flux-response relationships are recommended (Wieser and Tausz, 2006; UNECE, 2007).

Due to the evidence of widespread $\mathrm{O}_{3}$ damages to vegetation in Europe (Hayes et al., 2007), flux-response relationships have to be established and validated under field conditions for the economically most important crops and for the most sensitive vegetation types in $\mathrm{Eu}$ rope. These relationships have to be representative at local scale up to national scale. On the other hand, they have to serve as validation tools for the more general functions mentioned above. We briefly review here the toxicological background for the development of flux-effect relationships as well as the current status of flux measurement and modelling at leaf and canopy level. 


\section{Toxicological background for the develop- ment of flux-effect relationships}

The "classical" receptor model in toxicology relates the primary or initial response to an active species A (agonist, pharmacon) to the number or concentration of agonist-receptor-complexes (cf. Dämmgen and Grünhage, 1998). As a rule, for agonist as $\mathrm{O}_{3}$, which is not be accumulated, the concentrations of agonist and agonist-receptor-complexes at the target site can not be determined. Therefore, any initial response, i.e. perturbation according to Tingey and Taylor (1982), of a plant to $\mathrm{O}_{3}$ have to be described as a consequence of the influx, $\mathrm{F}_{\text {effective }}$, of the active chemical species to the target site (e.g. a membrane). The integral of $F_{\text {effective }}$ over time is the effective dose $\mathrm{D}_{\text {effective }}$, i.e.:

perturbation $=f_{1}\left(\mathrm{D}_{\text {effective }}\right)=f_{1}\left(\int_{\mathrm{t}_{1}}^{\mathrm{t}_{2}}\left|\mathrm{~F}_{\text {effective }}\right| \cdot \mathrm{dt}\right)$

The effective flux to the target site (e.g. a membrane) depends on the amount of molecular diffusion of $\mathrm{O}_{3}$ into the leaf interior (stomatal uptake, $\mathrm{F}_{\text {leaf, stom }}$ ) and is a function of the amount of detoxification, $\mathrm{F}_{\text {detoxification }}$ :

$$
\mathrm{F}_{\text {effective }}=\mathrm{F}_{\text {leaf, stom }}-\mathrm{F}_{\text {detoxification }}
$$

The integral of stomatal $\mathrm{O}_{3}$ uptake, $\mathrm{F}_{\text {leaf, stom, }}$, over time is the Accumulated stomatal Flux, $\mathrm{AF}_{\text {leaf, stom }}$, according to UNECE (2007) or the Pollutant $\underline{\text { Absorbed }}$ Dose, PAD, according to Fowler and Cape (1982).

$$
\mathrm{AF}_{\text {leaf }, \text { stom }}=\int_{\mathrm{t}_{1}}^{\mathrm{t}_{2}}\left|\mathrm{~F}_{\text {leaf, stom }}\right| \cdot \mathrm{dt}
$$

The initial response of a plant to the active species at the target site is always a function of the accumulated stomatal flux and the leaf detoxification capacity:

$$
\begin{gathered}
\text { perturbation }=f_{2}\left(\mathrm{AF}_{\text {leaf, stom }},\right. \\
\text { detoxification capacity }
\end{gathered}
$$

In general, the relation between $\mathrm{F}_{\text {leaf stom }}$ and the perturbation at a given time is described by a saturation curve with a no-effect threshold.

After perturbations, living organisms try to re-establish normal metabolism by repair and/or compensatory mechanisms. Any injury results from the inability of the respective plant to repair or compensate for changes of cellular functions and structures (Tingey and Taylor, 1982; Tingey and Andersen, 1991), i.e.:

$$
\begin{gathered}
\text { injury }=f_{3}\left(\mathrm{AF}_{\text {leaf, stom }}\right. \text {, detoxification } \\
\text { capacity, repair/compensatory capacity })
\end{gathered}
$$

The abovementioned threshold depends on the biological response parameter considered and on the capacity of detoxification, which is species-specific as well as daily and seasonally dynamic. This makes it difficult to parameterize the plant defence mechanisms. The relationship between stomatal uptake and effect does not obey the law of reciprocity, according to which equal doses generate equal effects. The same accumulated stomatal $\mathrm{O}_{3}$ uptake can cause more injury, shorter the time in which the dose is absorbed because of a premature depletion of the detoxification capacity. Therefore, statistically derived constant thresholds appear questionable.

While stomatal $\mathrm{O}_{3}$ uptake at leaf and canopy level can be derived from measurements (see subsequent sections) the effective flux can be modelled only. Weighting stomatal uptake and taking into account the frequency of occurrences of sequentially high fluxes can serve as a first attempt for $\mathrm{F}_{\text {effective }}$ as proposed by e.g. Grünhage and Jäger (1996) or Massman et al. (2000). In this context, future research efforts are necessary to establish a fully mechanistic approach of modelling plant detoxification/defence capacity (cf. Tausz et al., 2007).

\section{Flux measurement and modelling at leaf/ shoot level}

Total $\mathrm{O}_{3}$ fluxes at leaf level, $\mathrm{F}_{\text {leaf, total }}$, can be partitioned into fluxes (1) absorbed by the leaf through the stomata and the cuticle, $\mathrm{F}_{\text {leaf, stom\&cut, }}$ and (2) deposited on the external leaf surface, $\mathrm{F}_{\text {leaf, non-stom. }}$. Studies show that penetration through the cuticle can be neglected in comparison to stomatal uptake (cf. literature cited in Grünhage et al., 2000).

$$
\begin{gathered}
\mathrm{F}_{\text {leaf, total }}=\mathrm{F}_{\text {leaf, stom\&cut }}+\mathrm{F}_{\text {leaf, non-stom }} \\
\cong \mathrm{F}_{\text {leaf, stom }}+\mathrm{F}_{\text {leaf, non-stom }}
\end{gathered}
$$




\subsection{Flux measurement at leaf/shoot level}

Leaf and shoot scale fluxes can be measured by gas-exchange enclosure techniques. While several chamber designs for measuring water vapour $\left(\mathrm{H}_{2} \mathrm{O}\right)$ and carbon dioxide $\left(\mathrm{CO}_{2}\right)$ at leaf scale up to "canopy" scale of a few $\mathrm{m}^{2}$ are available, only three systems are used currently to measure $\mathrm{O}_{3}$ exchange directly. The system described by Altimir et al. $(2002,2004)$ and Kulmala et al. (1999) was designed for the purpose to measure shoot scale ambient $\mathrm{O}_{3}$ exchange only. Two other systems were designed for measuring $\mathrm{O}_{3}$ fluxes under different $\mathrm{O}_{3}$ regimes (ambient, elevated); the one described by Grulke et al. (2007) at leaf level, the one described by Havranek and Wieser (1994) and Wieser et al. (2001) at twig scale.

$\mathrm{F}_{\text {leat/shoot, total }}$ is determined from the $\mathrm{O}_{3}$ concentration change during chamber closure by solving the mass balance equation for the $\mathrm{O}_{3}$ concentration inside the chamber taking into account the flux produced by the chamber walls explicitly (Altimir system) or from the difference of $\mathrm{O}_{3}$ concentration of the air entering and leaving the chamber, the molar flow rate and the leaf/twig surface (Grulke and Wieser systems). Total leaf/shoot conductance, $\mathrm{g}_{\text {leaf/shoot, total, } \mathrm{O} 3}$, is defined by

$$
\left|\mathrm{F}_{\text {leaf/shoot, total,03 }}\right|=\mathrm{g}_{\text {leaf/shoot, total, O3 }} \cdot \rho_{03}
$$

with $\rho_{\mathrm{O} 3}$ the $\mathrm{O}_{3}$ partial density at chamber closure (Altimir system) or inside the chamber.

Total leaf/shoot conductance, $\mathrm{g}_{\text {leaf } / \text { shoot, total, O3, }}$, can be decomposed into leaf/shoot stomatal, $\mathrm{g}_{\text {leaf/shoot, stom, O3, }}$ and non-stomatal conductance, $\mathrm{g}_{\text {leaf/shoot, non-stom, O3, }}$

$$
\begin{gathered}
\mathrm{g}_{\text {leaf/shoot, total, O3 }}=\mathrm{g}_{\text {leaf } / \text { shoot, stom, O3 }}+ \\
\mathrm{g}_{\text {leaf/shoot, non-stom, O3 }}
\end{gathered}
$$

by calculating leaf/shoot scale stomatal water vapour conductance, $\mathrm{g}_{\text {leaf/shoot, stom, } \mathrm{H} 2 \mathrm{O}}$, from water vapour flux measurements or leaf/shoot scale stomatal carbon dioxide $\left(\mathrm{CO}_{2}\right)$ conductance, $\mathrm{g}_{\text {leaft/shoot, stom, } \mathrm{CO} 2}$, from $\mathrm{CO}_{2}$ flux measurements. Leaf/shoot conductance for $\mathrm{O}_{3}$ is related to that of water vapour or $\mathrm{CO}_{2}$ by the ratio the respective molecular diffusivities $\mathrm{D}_{\mathrm{A}}\left(\mathrm{A}=\mathrm{H}_{2} \mathrm{O}\right.$ or $\left.\mathrm{A}=\mathrm{CO}_{2}\right)$ :

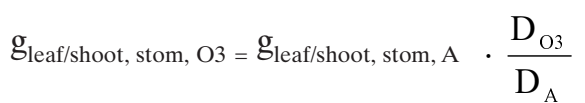

with $\mathrm{D}_{\mathrm{O} 3} / \mathrm{D}_{\mathrm{A}}=\mathrm{D}_{\mathrm{O} 3} / \mathrm{D}_{\mathrm{H} 2 \mathrm{O}}=0.66$ or $\mathrm{D}_{\mathrm{O} 3} /$ $\mathrm{D}_{\mathrm{A}}=\mathrm{D}_{\mathrm{O} 3} / \mathrm{D}_{\mathrm{CO} 2}=1.05$ according to the values given in Grünhage and Haenel (1997) and Massman (1998).

\subsection{Flux modelling at leaf level}

In general, actual $\mathrm{g}_{\text {leaf, stom, } \mathrm{O} 3}$ describes the dependency of stomatal aperture on radiation, temperature and the water budgets of atmosphere and soil (actually on the plant water status) as well as on the respective phenological development stage. Normally, these dependencies of actual $\mathrm{g}_{\text {leaf, stom }}$ are described by a multiplicative algorithm as e.g. given in eq. (10) according to the JarvisStewart approach (Jarvis, 1976; Stewart, 1988):

$$
\mathrm{g}_{\text {leaf, stom }}=\mathrm{g}_{\text {leaf, stom, max }} \cdot f_{\text {radiation }} \cdot f_{\text {temperature }} \cdot f_{\text {water vapour pressure deficit of the atmosphere }} \cdot f_{\text {soil moisture }} \cdot f_{\text {phenology }}
$$

where $\mathrm{g}_{\text {leaf, stom, } \max }$ represents the species-specific maximum stomatal conductance. Functions $f_{\mathrm{i}}$ account for the effects of the respective entity i on stomatal aperture, all expressed in relative terms as a proportion of $\mathrm{g}_{\text {leaf, stom, max }}\left(0 \leq f_{\mathrm{i}} \leq 1\right)$ and are derived from boundary line analysis, using experimental data (cf. e.g. Goumenaki et al., 2007; UNECE, 2007). Sometimes, the influence of $\mathrm{O}_{3}$ exposure (concentration or flux) and the time of day on stomatal aperture are considered (e.g. Goumenaki et al., 2007). The multiplicative algorithms published in the literature differ in the mathematical formulation of the respective Jarvis-Stewart functions $f_{\mathrm{i}}$ and in how they are considered.

It is convenient to assume that there are sinks in the leaf reducing the $\mathrm{O}_{3}$ concentrations to zero (Laisk et al., 1989; Wang et al., 1995). Because $\mathrm{O}_{3}$ concentration at the leaf surface can not be measured, flux estimations have to be based on $\mathrm{O}_{3}$ concentrations measured at some height above the canopy. Total $\mathrm{O}_{3}$ flux at leaf level, $\mathrm{F}_{\text {leaf, total }}$, is given by:

$$
\left|\mathrm{F}_{\text {leaf, total, } \mathrm{O} 3}\right|=\frac{\rho_{\mathrm{O} 3}\left(\mathrm{z}_{\text {ref }}\right)}{\mathrm{R}_{\text {atmos }}+\mathrm{R}_{\text {leaf boundary layer, } \mathrm{O} 3}+\mathrm{R}_{\text {leaf, total, } \mathrm{O} 3}}
$$


where $R_{\text {atmos }}$ is the atmospheric resistance representing the atmospheric transport properties between the $\mathrm{O}_{3}$ measurement height $\mathrm{z}_{\text {ref }}$ and upper surface of the laminar boundary layer of the respective leaf, $\mathrm{R}_{\text {leaf boundary layer, } \mathrm{O} 3}$ is leaf laminar boundary layer resistance for $\mathrm{O}_{3}$ representing the transport properties for $\mathrm{O}_{3}$ through the lam-

$$
\left|\mathrm{F}_{\text {leaf, stom, O3 }}\right|=\rho_{\mathrm{O} 3}\left(\mathrm{z}_{\text {ref }}\right) \cdot \mathrm{g}_{\text {leaf, stom, } \mathrm{H} 2 \mathrm{O}} \cdot \frac{\mathrm{D}_{\mathrm{O} 3}}{\mathrm{D}_{\mathrm{H} 2 \mathrm{O}}} \cdot \frac{\mathrm{R}_{\text {leaf } \text {, total, } \mathrm{O} 3}}{\mathrm{R}_{\text {atmos }}+\mathrm{R}_{\text {leaf boundary layer, } \mathrm{O} 3}+\mathrm{R}_{\text {leaf, total, O3 }}}
$$

While $\mathrm{R}_{\text {atmos }}$ is defined on canopy level only, $\rho_{\mathrm{O} 3}\left(\mathrm{z}_{\mathrm{ref}}\right)$ must represent the $\mathrm{O}_{3}$ partial density at the upper surface of the respective leaf

$$
\left|F_{\text {leaf, stom, } \mathrm{O} 3}\right|=\rho_{\mathrm{O} 3}\left(\mathrm{z}_{\text {leaf boundary layer }}\right) \cdot \mathrm{g}_{\text {leaf, stom, O3 }}
$$

UNECE (2007) assumes that the $\mathrm{O}_{3}$ concentration measured at canopy top represents a reasonable estimate of the concentration at the upper surface of the leaf laminar boundary layer of the sunlit upper canopy leaves (e.g. the flag leaf in the case of wheat). At the moment, the uncertainties associated with this assumption is unknown. Because Parameterizations for $\mathrm{g}_{\text {leaf, non stom }}$ are currently not available, a con- inar boundary layer to the leaf surface and $\mathrm{R}_{\text {leaf, total, O3 }}$ is the total leaf resistance for $\mathrm{O}_{3}$ $\left(\mathrm{R}_{\text {leaf, total }}=1 / \mathrm{g}_{\text {leaf, total }}\right)$.

The toxicologically potential active fraction of $\mathrm{O}_{3}$ absorbed by the leaf through the stomata (i.e. detoxification is not considered at this stage) is given by:

laminar boundary layer, $\rho_{\mathrm{O} 3}\left(\mathrm{z}_{\text {leaf laminar boundary lay- }}\right.$ $\left.{ }_{\text {er }}\right)$, formally. With $\rho_{\mathrm{O} 3}\left(\mathrm{z}_{\text {ref }}\right)=\rho_{\mathrm{O} 3}\left(\mathrm{z}_{\text {leaf laminar bound- }}\right.$ ary layer) eq. (12) reduces to:

$$
\frac{\mathrm{R}_{\text {leaf }, \text { total, } \mathrm{O} 3}}{\mathrm{R}_{\text {leaf boundary layer, } \mathrm{O} 3}+\mathrm{R}_{\text {leaf, total, } \mathrm{O3}}}
$$

stant value of $1 / 2500 \mathrm{~m} / \mathrm{s}$ is recommended by UNECE (2007).

Robust relationships have been developed for estimation the leaf laminar boundary layer resistance. $\mathrm{R}_{\text {leaf boundary layer }}$, computed using flat plate theory, depends on characteristic crosswind leaf dimension, $\mathrm{L}_{\text {leaf }}$, and wind speed at the respective leaf layer height, $\mathrm{z}_{\text {leaf laver i }}$ (cf. McNaughton and van den Hurk, 1995):

$$
\mathrm{R}_{\text {leaf boundary layer, } \mathrm{O} 3}=\left(150 \cdot \beta \cdot \sqrt{\frac{\mathrm{L}_{\text {leaf }}}{\mathrm{u}\left(\mathrm{Z}_{\text {leaf layer } \mathrm{i}}\right)}}\right) \cdot \alpha
$$

where units for $\mathrm{R}_{\text {leaf boundary layer }}$ and $\mathrm{u}\left(\mathrm{z}_{\text {leaf layer } \mathrm{i}}\right)$ are $\mathrm{s} / \mathrm{m}$, respectively, and the constant 150 has unit $\mathrm{s}^{0.5} / \mathrm{m}$. While the definition of an appropriate characteristic crosswind leaf dimension, $\mathrm{L}_{\text {leaf }}$, the unit of which is $\mathrm{m}$, is relatively obvious for standard geometric shapes (e.g. plate), it is less for leaves and plant elements with often irregular shapes (for a brief discussion see Schuepp, 1993). For wheat, potato and beech/birch values of $0.02 \mathrm{~m}, 0.04 \mathrm{~m}$ and $0.05 \mathrm{~m}$ respectively are recommended by UNECE (2007). According to McNaughton and van den Hurk (1995), the dimensionless heat transfer enhancement ratio, $\beta$, depends on the effects e.g. of irregular leaf shapes, small-scale turbulence and mutual sheltering of leaves. As a plausible general choice the value $\beta=1$ is recommended by the before mentioned authors. The height dependence of wind speed within the canopy is often described by an exponential function (cf. Cionco, 1965, 1972). Because the cumulative stomatal flux-based critical levels for agricultural crops and the provisional one for sensitive forest are based on flux estimates for the uppermost leaf level that is directly exposed to solar radiation (UNECE, 2007), wind speed measured at canopy top represents $\mathrm{u}\left(\mathrm{Z}_{\text {leaf layer } \mathrm{i}}\right)$. With $\alpha=1.3$ the differences in diffusivity between sensible heat and $\mathrm{O}_{3}$ are taken into account.

\section{Flux measurement and modelling at canopy level}

Similarly as $\mathrm{F}_{\text {leaf, total }}$, total $\mathrm{O}_{3}$ fluxes at canopy level, $\mathrm{F}_{\text {canopy, total }}$, can be partitioned into fluxes (1) absorbed by the leaves through the stomata and the cuticles, $\mathrm{F}_{\text {canopy, stom\&cut }}$, and (2) de- 


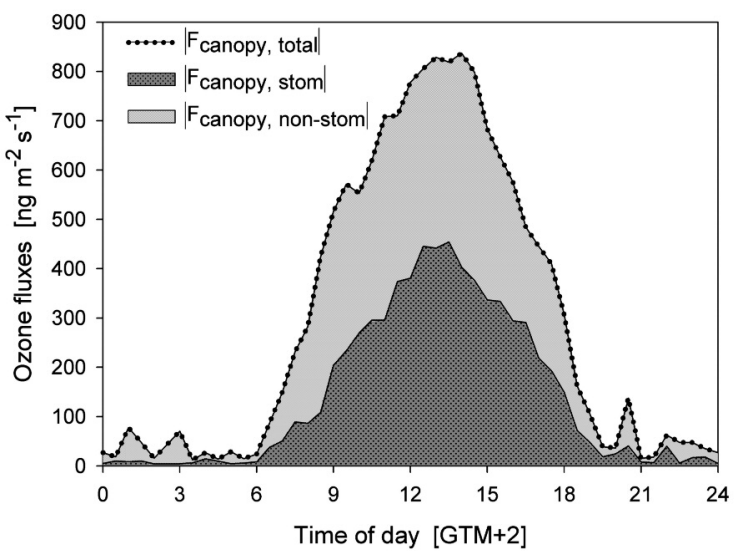

Figure 1. Mean diurnal variation of stomatal and total $\mathrm{O}_{3}$ flux measured above a barley field at Comun Nuovo (Italy) from anthesis to harvest ( $7^{\text {th }}$ May to $5^{\text {th }}$ June) in 2002 (adapted from Gerosa et al., 2004).

posited on the external plant surfaces and the soil, $\mathrm{F}_{\text {canopy, non-stom }}$, and penetration through the cuticle can be neglected in comparison to stomatal uptake.

$$
\begin{aligned}
& \mathrm{F}_{\text {canopy, total }}=\mathrm{F}_{\text {canopy, stom\&cut }}+\mathrm{F}_{\text {canopy, non-stom }} \\
& \cong \mathrm{F}_{\text {canopy, stom }}+\mathrm{F}_{\text {canopy, non-stom }}
\end{aligned}
$$

Many studies illustrate that non-stomatal $\mathrm{O}_{3}$ deposition can be an important and not negligible part of total $\mathrm{O}_{3}$ canopy flux as shown e.g. in Figure 1.

\subsection{Flux measurement at canopy level}

If a vertical flux density, $\mathrm{F}_{\text {canopy }}$, measured in the atmospheric surface layer at some reference height, $\mathrm{z}_{\mathrm{ref}}$, above the canopy shall reflect the exchange at the surface,

$$
\mathrm{F}_{\text {canopy, surface }}=\mathrm{F}_{\text {canopy, }} \mathrm{z}_{\text {ref }}
$$

the atmospheric surface layer must satisfy the conditions of the so-called 'constant-flux layer'.

From the general budget equation for trace gases one can deduce that the desired constantflux situation is met if the following postulates are satisfied (cf. e.g. Grünhage et al., 2000):

1) stationarity, i.e. the change of the respective meteorological entity with time is zero,
2) horizontal homogeneity of the plant/soil system (fetch problem),

3) no horizontal advection,

4) no chemical sources and sinks between the reference height and the surface,

5) zero mean vertical wind velocity and

6) vertical transport by molecular diffusion can be neglected (which is generally the case except very near the plant and soil surfaces).

If all these postulates are met, the general budget equation is reduced to the eddy covariance equation (first applied by Swinbank, 1951)

$$
\mathrm{F}_{\text {canopy, } \mathrm{X}}=\overline{\mathrm{w}^{\prime} \cdot \mathrm{X}^{\prime}}
$$

with w' the fluctuation of vertical wind velocity, $w$, and $X^{\prime}$ the fluctuation of horizontal wind velocity, $\mathrm{u}$, or absolute air temperature, $\mathrm{T}$, or partial density of trace gas A, $\rho$. The eddy covariance technique is the most elegant of the micrometeorological methods.

To sample the whole spectrum of flux-carrying eddies, the instruments must be capable of detecting the high frequency structure of $w$ and, in the case of ozone, of $\rho_{\mathrm{O} 3}$ thus requiring a response time of at least $0.1 \mathrm{~s}$ for measurements above short vegetation (e.g. wheat, grassland).

A second class of methods, the aerodynamic profile methods, rely on the relationship between turbulent fluxes and vertical time averaged gradients. $\mathrm{O}_{3}$ flux is calculated by multiplying e.g. a half-hourly concentration difference with a calculated turbulent transfer coefficient $\lambda_{\text {atmosphere }}$ :

$$
\mathrm{F}_{\text {canopy, O3 }}=-\lambda_{\text {atmosphere }} \cdot \Delta \bar{\rho}_{\mathrm{O} 3}
$$

The methods currently used in the BIAFLUX community, differ in how $\lambda_{\text {atmosphere }}$ is estimated (cf. Fowler et al., 2001; Mikkelsen et al., 2000, 2004; Coyle et al., 2006). The approach given in eq. (19) for example, makes use of sonic measured friction velocity, $\mathrm{u}_{*}$, and a Monin-Obukhov length, $\mathrm{L}$, and displacement height, d, derived from eddy covariance measurements of sensible heat and measurements of air temperature, relative air humidity, atmospheric pressure and wind velocities at two heights, $\mathrm{z}_{1}$ and $\mathrm{z}_{2}\left(z_{1}<z_{2}\right)$,

$$
\lambda_{\text {atmosphere }}=\frac{\kappa \cdot \mathrm{u}_{*}}{\ln \left(\frac{\mathrm{z}_{2}-\mathrm{d}}{\mathrm{z}_{1}-\mathrm{d}}\right)-\Psi_{\mathrm{h}}\left(\frac{\mathrm{z}_{2}-\mathrm{d}}{\mathrm{L}}\right)+\Psi_{\mathrm{h}}\left(\frac{\mathrm{z}_{1}-\mathrm{d}}{\mathrm{L}}\right)}
$$


where $\Psi_{\mathrm{h}}$ is the integrated atmospheric stability function for sensible heat and $\kappa$ is the dimensionless von Kármán's constant.

Because the before mentioned postulates are never fully satisfied, several corrections and quality tests are necessary to guarantee flux data sets of high accuracy. A comprehensive discussion of correction procedures can be found in Lee et al. (2004). For example, the correction considers the influences of trace gas density fluctuations due to simultaneous transfer of sensible and latent heat (cf. Webb et al., 1980). The Schotanus/Liu correction is applied to sonic temperature and sensible heat flux (Liu et al., 2001). Again, in practice the coordinate systems of the sonic anemometer and the surface will not be perfectly aligned causing a non-zero mean vertical wind velocity. This effect can be corrected by coordinate rotation (cf. Wilczak et al., 2001): in a first rotation the streamwise component is rotated in the direction of the mean horizontal wind vector, in a second one the coordinate system is tilted so that mean vertical wind velocity becomes zero. Several tests are available to check the fulfilment of the theoretical requirements of adequate fetch (footprint analysis; cf. e.g. Schuepp et al., 1990; Haenel and Grünhage, 1999), of stationarity (steady state test; cf. e.g. Foken and Wichura, 1996) and of well developed turbulent conditions (comparison of measured and modelled integral turbulent characteristics; cf. e.g. Thomas and Foken, 2002).

Not least, $\mathrm{O}_{3}$ flux densities measured in the atmospheric surface layer at some height above the canopy are biased in principle due to the reaction of $\mathrm{O}_{3}$ with $\mathrm{NO}$ emitted by the soil. Nevertheless, in most cases the effect of air chemistry on $\mathrm{O}_{3}$ fluxes is negligible during daylight hours, as described by several authors (cf. literature cited in Grünhage et al., 2000).

Measurements of meteorological parameters are normally reduced to one set of instruments, without replication. Especially the gradient methods are sensible to the patchiness of the vegetation and soil, even in ecosystems which are normally considered to be horizontally homogeneous (cf. Dämmgen et al., 2005).

\subsection{Flux modelling at canopy level}

Modelling of biosphere/atmosphere exchange of gases as well as of aerosols depends on the res- olution in space and time needed. Whereas lo-

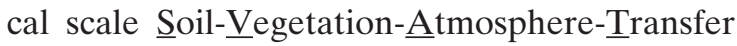
(SVAT) models rely on the detailed description of the canopy energy balance of the ecosystem under consideration (cf. e.g. Grünhage et al., 2000), regional or national scale models make use of simplifying and integrating assumptions and make use of typical deposition velocities rather than site-specific driving forces (cf. Erisman et al., 2005). At the European scale, flux estimates are based on large-scale modelled meteorology and concentration fields; ecosystem properties are replaced by those of a vegetation type (cf. Grünhage et al., 2004). Necessarily, the complexity of details and processes considered in flux modelling decreases with increasing scale in space and in time. This means that those generalized approaches must be carefully calibrated by well validated local scale models.

SVAT models serve for two purposes: (1) in agricultural and forest meteorology they are used to calculate water dynamics e.g. to predict irrigation; (2) in the context of the ecotoxicology of air constituents they are needed to derive dose-response relationships at canopy scale (cf. Dämmgen and Grünhage, 1998).

The SVAT models described in the literature can be grouped into the following categories: (1) schemes with one-dimensional (z direction) and (2) schemes with three-dimensional (x, y, z direction) parameterization of canopy trace gas exchange. The class of SVAT schemes with onedimensional characterization of the canopy comprises schemes with a single-layered resolution of vegetation (big-leaf approach: cf. e.g. Grünhage and Haenel, 1997; Gerosa et al., 2003; Bassin et al., 2004; Bleeker et al., 2004; singlelayered sun/shade model: cf. Grünhage and Haenel, 2008), a two-layered and a multi-layered resolution of vegetation (cf. Pieterse et al., 2007; literature cited in Grünhage et al., 2000).

The big-leaf concept assumes that the vertical distribution of sources and/or sinks of a scalar (sensible heat, latent heat or other trace gas) can be represented by a single source and/or sink at the surface of a big-leaf, which

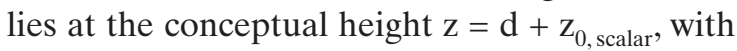
$z_{0 \text {, scalar }}$ representing either the roughness length for sensible heat $\left(\mathrm{z}_{0 \mathrm{~h}}\right)$ or a trace gas species $\left(\mathrm{z}_{0 \mathrm{c}}\right)$. Figure 2 shows this concept applied to $\mathrm{O}_{3}$ (ignoring the generally weak sinks or sources of 
$\mathrm{O}_{3}$ due to chemical reactions in the surface layer during daylight hours).

If a plant/soil system can be considered a perfect sink as is usually assumed for the ex- change of $\mathrm{O}_{3}$, the vertical turbulent exchange of $\mathrm{O}_{3}$ between the phytosphere and the atmosphere near the surface can be modelled by:

$$
\mathrm{F}_{\text {canopy }, \mathrm{O} 3}=-\frac{\rho_{\mathrm{O} 3}\left(\mathrm{z}_{\mathrm{ref}, \mathrm{O} 3}\right)}{\mathrm{R}_{\mathrm{ah}}\left(\mathrm{d}+\mathrm{z}_{\mathrm{Om}}, \mathrm{z}_{\mathrm{ref}, \mathrm{O} 3}\right)+\mathrm{R}_{\mathrm{b}, \mathrm{O} 3}+\mathrm{R}_{\mathrm{c}, \mathrm{O} 3}}
$$

The parameterization of the turbulent atmospheric resistance, $\mathrm{R}_{\mathrm{ah}}$,

$$
\mathrm{R}_{\mathrm{ah}}\left(\mathrm{d}+\mathrm{z}_{0 \mathrm{~m}}, \mathrm{z}_{\mathrm{ref}, 03}\right)=\frac{\ln \left(\frac{\mathrm{z}_{\mathrm{ref}, \mathrm{O} 3}-\mathrm{d}}{\mathrm{z}_{0 \mathrm{~m}}}\right)-\Psi_{\mathrm{h}}\left(\frac{\mathrm{z}_{\mathrm{ref}, 03}-\mathrm{d}}{\mathrm{L}}\right)+\Psi_{\mathrm{h}}\left(\frac{\mathrm{z}_{0 \mathrm{~m}}}{\mathrm{~L}}\right)}{\kappa \cdot \mathrm{u}_{*}}
$$

describing the transport properties for $\mathrm{O}_{3}$ between a reference height $\left(\mathrm{z}_{\text {ref, O3 }}\right)$ above the canopy and the conceptual momentum sink

$$
\mathrm{R}_{\mathrm{b}, 03}=\mathrm{R}_{\mathrm{b}, \text { heat }} \cdot\left(\frac{\mathrm{Sc}_{\mathrm{O} 3}}{\operatorname{Pr}}\right)^{\frac{2}{3}}=\frac{\ln \left(\frac{\mathrm{z}_{0 \mathrm{~m}}}{\mathrm{z}_{0 \mathrm{~h}}}\right)-\Psi_{\mathrm{h}}\left(\frac{\mathrm{z}_{0 \mathrm{~m}}}{\mathrm{~L}}\right)+\Psi_{\mathrm{h}}\left(\frac{\mathrm{z}_{0 \mathrm{~h}}}{\mathrm{~L}}\right)}{\kappa \cdot \mathrm{u}_{*}} \cdot 1.19
$$

describing the transport properties for $\mathrm{O}_{3}$ between momentum sink height and the $\mathrm{O}_{3}$ sink height $\left(\mathrm{z}=\mathrm{d}+\mathrm{z}_{0 \mathrm{c}}=\mathrm{d}+\mathrm{z}_{0 \mathrm{~h}}\right)$ are well accepted. The bulk canopy resistance for $\mathrm{O}_{3}, \mathrm{R}_{\mathrm{c}, \mathrm{O}}$, represents a combination of resistances characterizing the fluxes through the leaf stomata height $\left(\mathrm{z}=\mathrm{d}+\mathrm{z}_{0 \mathrm{~m}}\right)$ as well as the parameterization of the quasi-laminar layer resistance, $\mathrm{R}_{\mathrm{b}, \mathrm{O} 3}$,

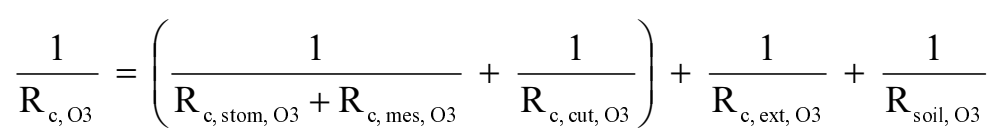

In eq. (23) an in-canopy transfer resistance is not taken into account for two reasons: (1) an in-canopy transfer resistance seems to be in contradiction to the big-leaf concept which does not distinguish between the levels of soil and canopy sources or sinks; and (2) if one use $\ln \left(\mathrm{z}_{0 \mathrm{~m}} / \mathrm{z}_{0 \mathrm{~h}}\right)=2$ to estimate $\mathrm{R}_{\mathrm{b}}$ according to eq. (22) the effect of in-canopy transfer seems to be implicitly accounted for in the value of $\mathrm{z}_{0 \mathrm{~h}}$ (for further informations see Grünhage et al., 2000).

Big-leaf models, often based on the canopy energy balance, differ mainly in how $R_{c, O 3}$ is scaled according to the canopy development stage. In the PLant-ATmosphere INteraction (PLATIN; Grünhage and Haenel, 2008) model for example, this scaling depends on the fraction of radiation absorbed by the sunlit and the
$\left(\mathrm{R}_{\mathrm{c} \text {, stom, O3 }}\right)$, into or out the mesophyll tissue $\left(R_{c, \text { mes, O3 }}\right)$, through the cuticle of the leaves $\left(R_{c, \text { cut }, \mathrm{O} 3}\right)$, to external plant surfaces $\left(\mathrm{R}_{\mathrm{c}, \mathrm{ext}, \mathrm{O} 3}\right)$, and down to the soil surface $\left(R_{\text {soil, O3 }}\right)$. For a given canopy development stage, $R_{c, \text { O3 }}$ is given by: shaded leaf fraction of the canopy.

The bulk stomatal resistance for $\mathrm{O}_{3}$ is related to that of water vapour by the ratio the respective molecular diffusivities D

$$
\mathrm{R}_{\mathrm{c}, \mathrm{stom}, \mathrm{O3}}=\mathrm{R}_{\mathrm{c}, \mathrm{stom}, \mathrm{H} 2 \mathrm{O}} \cdot \frac{\mathrm{D}_{\mathrm{H} 2 \mathrm{O}}}{\mathrm{D}_{\mathrm{O} 3}}
$$

where $R_{c, \text { stom, O3 }}$ is parameterized similar to the leaf-level stomatal conductance described by eq. (10).

Greater uncertainties can be noticed with respect of the parameterization of the nonstomatal resistances, especially of $\mathrm{R}_{\mathrm{c} \text {, ext, O3 }}$ controlling non-stomatal deposition in a closed, dense canopy. The resistance can be estimated as the residual term in the bulk canopy resistance if bulk stomatal resistance is known. 


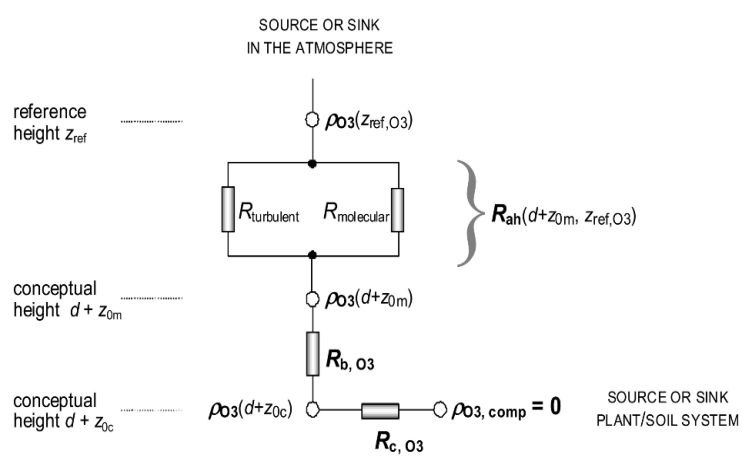

Figure 2. Resistance analogue of $\mathrm{O}_{3}$ exchange between the atmospheric surface layer and terrestrial ecosystems as used for the big-leaf concept (adapted from Grünhage et al., 2000).

$\mathrm{R}_{\mathrm{c} \text {, non-stomatal, } \mathrm{O} 3}$ components are often parameterized by constant values neglecting e.g. the effect of surface wetness on the sink properties for $\mathrm{O}_{3}$ which should important in some cases (Altimir et al., 2004; Zhang et al. 2002). The increase of non-stomatal deposition, i.e. the re-

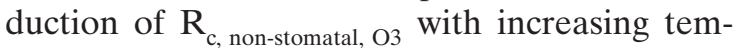
perature and radiation is regarded as evidence of thermal decomposition of $\mathrm{O}_{3}$ at the external plant surfaces (Fowler et al., 2001).

\subsection{Direct calculation of stomatal $\mathrm{O}_{3}$ uptake at canopy level}

With total fluxes obtained from measurements, canopy stomatal $\mathrm{O}_{3}$ uptake can be calculated making use of a resistance analogue as illustrated in Figure 2 (cf. Gerosa et al., 2005). The turbulent atmospheric resistance and the quasilaminar layer resistance can be derived from sonic measured friction velocity and sensible heat flux and from measured air temperature, relative air humidity, air pressure and horizontal wind velocities at two heights. The canopy resistance can then be determined as a residual. Considering that the flux is constant along the vertical axis between the reference height $\left(\mathrm{z}_{\mathrm{ref}, \mathrm{O} 3}\right)$ and the $\mathrm{O}_{3}$ sink height $\left(\mathrm{z}=\mathrm{d}+\mathrm{z}_{0 \mathrm{c}}\right)$, the $\mathrm{O}_{3}$ concentration $\rho_{\mathrm{O} 3}\left(d+z_{0 \mathrm{c}}\right)$ can be properly calculated. At the conceptual height $\mathrm{z}=\mathrm{d}+\mathrm{z}_{0 \mathrm{c}}$ total $\mathrm{O}_{3}$ flux divides into a stomatal contribution and a non-stomatal one. Stomatal uptake is regulated by the stomatal resistance for $\mathrm{O}_{3}$, which is related to that of water vapour by the ratio of the respective molecular diffusivities. These considerations yield in a formulation for canopy stomatal $\mathrm{O}_{3}$ uptake with bulk canopy stomatal resistance for water vapour as the only unknown parameter:

$$
\left|\mathrm{F}_{\text {canopy, stom, O3 }}\right|=\rho_{\mathrm{O} 3}\left(\mathrm{z}_{\mathrm{ref}}\right) \cdot \frac{\mathrm{R}_{\mathrm{c}, \mathrm{O} 3}}{\left[\mathrm{R}_{\mathrm{ah}}\left(\mathrm{d}+\mathrm{z}_{\mathrm{Om}}, \mathrm{z}_{\mathrm{ref}, \mathrm{O} 3}\right)+\mathrm{R}_{\mathrm{b}, \mathrm{O} 3}+\mathrm{R}_{\mathrm{c}, \mathrm{O} 3}\right] \cdot \mathrm{R}_{\mathrm{c}, \mathrm{stom}, \mathrm{H} 2 \mathrm{O}} \cdot \mathrm{D}_{\mathrm{H} 2 \mathrm{O}} / \mathrm{D}_{\mathrm{O} 3}}
$$

If transpiration is the only source of water vapour from the plant/soil system, bulk stomatal resistance for water vapour equals the bulk canopy resistance $\left(\mathrm{R}_{\mathrm{c}, \text { stom, } \mathrm{H} 2 \mathrm{O}}=\mathrm{R}_{\mathrm{c}, \mathrm{H} 2 \mathrm{O}}\right)$. It is normally as- sumed that this assumption is practically satisfied if the soil is covered by a closed, dense canopy. For such conditions, $\mathrm{R}_{\mathrm{c} \text {, stom, } \mathrm{H} 2 \mathrm{O}}$ can be obtained by inverting the Penman-Monteith equation:

$$
\lambda E=\frac{\mathrm{s}_{\mathrm{c}} \cdot\left(\mathrm{R}_{\text {net }}-\mathrm{G}\right)+\rho_{\text {moist air }} \cdot \mathrm{c}_{\mathrm{p}, \text { moist air }} \cdot \frac{\mathrm{VPD}}{\mathrm{R}_{\mathrm{ah}}\left(\mathrm{d}+\mathrm{z}_{0 \mathrm{~m}}, \mathrm{z}_{\text {ref, } \mathrm{T}}\right)+\mathrm{R}_{\mathrm{b}, \text { heat }}}}{\mathrm{s}_{\mathrm{c}}+\gamma \cdot \frac{\mathrm{R}_{\mathrm{ah}}\left(\mathrm{d}+\mathrm{z}_{0 \mathrm{~m}}, \mathrm{z}_{\text {ref, } \mathrm{T}}\right)+\mathrm{R}_{\mathrm{b}, \mathrm{H} 2 \mathrm{O}}+\mathrm{R}_{\mathrm{c}, \mathrm{H} 2 \mathrm{O}}}{\mathrm{R}_{\mathrm{ah}}\left(\mathrm{d}+\mathrm{z}_{0 \mathrm{~m}}, \mathrm{z}_{\mathrm{ref}, \mathrm{T}}\right)+\mathrm{R}_{\mathrm{b}, \text { heat }}}}
$$

with $\lambda \mathrm{E}$ the turbulent vertical flux density of latent heat, $R_{n e t}$ the net radiative flux, $G$ the ground heat flux, $c_{p \text {, moist air }}$ and $\rho_{\text {moist air }}$ the heat capacity and the density of moist air respectively, VPD the difference of water vapour pressure between the saturated and the actual air, $\gamma$ the psychrometric constant equal to $65.5 \mathrm{~Pa} / \mathrm{K}$ and $\mathrm{s}_{\mathrm{c}}$ the slope of the Clausius-Clapeyron function of saturated air vapour pressure at the actual temperature.
All parameters given in eq. (26) can be measured directly or derived from measurements.

Another, more direct, approach is given by eqs. (27) - (29) according to e.g. Coe et al. (1995). For this approach net radiation and ground heat flux is not needed. $\mathrm{R}_{\mathrm{c}, \mathrm{H} 2 \mathrm{O}}$ is calculated from the water vapour pressure deficit at the conceptual source/sink height for sensible and the latent heat flux: 


$$
\begin{aligned}
& \mathrm{T}_{\mathrm{s}}=\mathrm{T}\left(\mathrm{z}_{\text {ref }, \mathrm{T}}\right)+\frac{\mathrm{H} \cdot\left(\mathrm{R}_{\mathrm{ah}}\left(\mathrm{d}+\mathrm{z}_{0 \mathrm{~m}}, \mathrm{z}_{\text {ref }, \mathrm{T}}\right)+\mathrm{R}_{\mathrm{b}, \text { heat }}\right)}{\rho_{\text {moist air }} \cdot \mathrm{c}_{\mathrm{p}, \text { moist air }}} \\
& \mathrm{e}\left(\mathrm{d}+\mathrm{z}_{0 \mathrm{~h}}\right)=\mathrm{e}\left(\mathrm{z}_{\mathrm{ref}, \mathrm{T}}\right)+\frac{\left(\lambda \mathrm{E} \cdot \lambda^{-1}\right) \cdot \mathrm{p}}{0.622 \cdot \rho_{\text {moist air }}} \cdot\left(\mathrm{R}_{\mathrm{ah}}\left(\mathrm{d}+\mathrm{z}_{0 \mathrm{~m}}, \mathrm{z}_{\mathrm{ref}, \mathrm{T}}\right)+\mathrm{R}_{\mathrm{b}, \text { heat }}\right) \\
& \mathrm{R}_{\mathrm{c}, \mathrm{H} 2 \mathrm{O}}=\frac{0.622 \cdot \rho_{\text {moist air }}}{\mathrm{p}} \cdot \frac{\mathrm{e}_{\mathrm{sat}}\left(\mathrm{d}+\mathrm{z}_{\mathrm{hh}}\right)-\mathrm{e}\left(\mathrm{d}+\mathrm{z}_{0 \mathrm{~h}}\right)}{\lambda \mathrm{E} \cdot \lambda^{-1}}
\end{aligned}
$$

However the two models have been proven to be equivalent, either formally and practically (Gerosa et al., 2007).

In reality, the before mentioned assumption of zero evaporation rates from soil below canopies is never satisfied. This results in a slight overestimation of $\mathrm{R}_{\mathrm{c}, \text { stom, } \mathrm{H} 2 \mathrm{O}}$ and consequently in a slight underestimation of estimated transpiration rates and stomatal $\mathrm{O}_{3}$ uptake.

For single trees $\mathrm{R}_{\mathrm{c}, \mathrm{H} 2 \mathrm{O}}$ can be also derived from sap flow measurements (cf. e.g. Wieser et al., 2006).

\section{Conclusions and future research needs}

$\mathrm{O}_{3}$ flux measurement techniques at canopy level are well established, while modelling of $\mathrm{O}_{3}$ exchange is associated with greater uncertainties. Stomatal $\mathrm{O}_{3}$ conductance parameterization depends on a representative maximum stomatal conductance, $g_{\max , 03}$, at leaf as well as at canopy level. Standardized protocols for the derivation of $g_{\max }$ especially for the leaf level are needed. In the context of $\mathrm{O}_{3}$ exchange modelling, future research has to focus on the derivation of parameterizations of the non-stomatal $\mathrm{O}_{3}$ resistance. Canopy resistances derived from measurements can be used for model calibration and validation.

Because the current flux-effect relationships proposed by UNECE (2007) are based on stomatal $\mathrm{O}_{3}$ uptake calculations for a sunlit leaf at the top of the canopy, an implementation of a single-layered sun/shade sub-model in SVAT models based on the big-leaf concept is recommended. This allows partitioning of bulk stomatal $\mathrm{O}_{3}$ uptake into stomatal uptake by the sunlit and the shaded leaf fraction of the canopy. Taking into account the total leaf area index of the sunlit leaf fraction of the canopy, stomatal
$\mathrm{O}_{3}$ uptake per unit of projected leaf area as well as stomatal conductance of the sunlit leaves can be estimated. This recalculation of stomatal conductance of sunlit leaves from bulk stomatal conductance may serve as a direct interface between canopy and leaf scale measurements as well as between micrometeorological and impact research. Besides verification of the parameterization of bulk stomatal conductance via measurements of canopy level water vapour exchange, big-leaf stomatal conductance parameterizations and water vapour fluxes can be compared directly with porometer measurements on the leaf level. Up-scaling algorithm from leaf to canopy level can then be verified or adjusted.

\section{References}

Altimir N., Tuovinen J.P., Vesala T., Kulmala M., Hari P. 2004. Measurements of ozone removal by Scots pine shoots: calibration of a stomatal uptake model including the non-stomatal component. Atmospheric Environment, 38:2387-2398.

Altimir N., Vesala T., Keronen P., Kulmala M., Hari P. 2002. Methodology for direct field measurements of ozone flux to foliage with shoot chambers. Atmospheric Environment, 36:19-29.

Ashmore M.R., Wilson R.B. 1992. Critical levels of air pollutants for Europe. Background papers prepared for the United Nations Economic Commission for Europe workshop on Critical Levels. Egham (UK), March 23-26, 1992. Air Quality Division, Department of the Environment, London.

Bassin S., Calanca P., Weidinger T., Gerosa G., Fuhrer E. 2004. Modeling seasonal ozone fluxes to grassland and wheat: model improvement, testing, and application. Atmospheric Environment, 38:2349-2359.

Bleeker A., Reinds G.J., Vermeulen A.T., de Vries W., Erisman J.W. 2004. Critical loads and present deposition thresholds of nitrogen and acidity and their exceedance at level II and level I monitoring plots in Europe. ECN report no. ECN-C-04-117. Energy research Centre of the Netherlands. 
Cionco R.M. 1965. A mathematical model for airflow in a vegetative canopy. Journal of Applied Meteorology, 4:517-522.

Cionco R.M. 1972. A wind-profile index for canopy flow. Boundary-Layer Meteorology, 3:255-263.

Coe H., Gallagher M.W., Choularton T.W., Dore C. 1995. Canopy scale measurements of stomatal and cuticular $\mathrm{O}_{3}$ uptake by Sitka spruce. Atmospheric Environment, 29:1413-1423.

Coyle M., Fowler D., Nemitz E., Philips G., StoretonWest R., Thomas R. 2006. Field measurements of the ozone flux to vegetation. In: Ozone Umbrella: Effects of Ground-level Ozone on (Upland) Vegetation in the UK. DEFRA Contract 1/3/201. CEH C02158 Report No. AS 06/02.

Dämmgen U., Grünhage L. 1998. Response of a grassland ecosystem to air pollutants. V. A toxicological model for the assessment of dose-response relationships for air pollutants and ecosystems. Environmental Pollution, 101:375-380.

Dämmgen U., Grünhage L., Haenel H.-D., Jäger H.J. 1993. Climate and stress in ecotoxicology. A coherent system of definitions and terms. Angewandte Botanik, 67:157-162.

Dämmgen U., Grünhage L., Schaaf S. 2005. The precision and spatial variability of some meteorological parameters needed to determine vertical fluxes of air constituents. Landbauforschung Völkenrode, 55:29-37.

Dentener F., Stevenson D., Cofala J., Mechler R., Amann M., Bergamaschi P., Raes F., Derwent R. 2005. The impact of air pollutant and methane emission controls on tropospheric ozone and radiative forcing: CTM calculations for the period 1990-2030. Atmospheric Chemistry and Physics, 5:1731-1755.

Erisman J.W., Vermeulen A., Hensen A., Flechard C., Dämmgen U., Fowler D., Sutton M., Grünhage L., Tuovinen J.-P. 2005. Monitoring and modelling of biosphere/atmosphere exchange of gases and aerosols in Europe. Environmental Pollution, 133:403-413.

EU 2002. Directive 2002/3/EC of the European Parliament and of the Council of 12 February 2002 relating to ozone in ambient air. Official Journal of the European Communities L 067, 09/03/2002, 14-30.

Foken Th., Wichura B. 1996. Tools for quality assessment of surface-based flux measurements. Agricultural and Forest Meteorology, 78:83-105.

Fowler D., Cape J.N. 1982. Air pollutants in agriculture and horticulture. In: Unsworth M.H., Ormrod D.P. (eds.): Effects of gaseous air pollution in agriculture and horticulture, 3-26. Butterworth Scientific, London.

Fowler D., Flechard C., Cape J.N., Storeton-West R.L., Coyle M. 2001. Measurements of ozone deposition to vegetation quantifying the flux, the stomatal and nonstomatal components. Water, Air \& Soil Pollution, 130:63-74.

Fuhrer J., Achermann B. 1994. Critical levels for ozone
- a UN-ECE workshop report. FAC Schriftenreihe (Eidgenössische Forschungsanstalt für Agrikulturchemie und Umwelthygiene, Bern), 16.

Fuhrer J., Achermann B. 1999. Critical Levels for Ozone - Level II. Environmental Documentation 115. Swiss Agency for the Environment, Forests and Landscape, Bern, Switzerland.

Gerosa G., Cieslik S., Ballarin-Denti A. 2003. Micrometeorological determination of time-integrated stomatal ozone fluxes over wheat: a case study in Northern Italy. Atmospheric Environment, 37:777-788.

Gerosa G., Derghi F., Cieslik S. 2007. Comparison of different algorithms for stomatal ozone flux determination from micrometeorological measurements. Water, Air \& Soil Pollution, 179:309-321.

Gerosa G., Marzuoli R., Cieslik S., Ballarin-Denti A. 2004. Stomatal ozone fluxes over a barley field in Italy. "Effective exposure" as a possible link between exposure- and flux-based approaches. Atmospheric Environment, 38:2421-2432.

Gerosa G., Vitale M., Finco A., Manes F., Bellarin Denti A., Cieslik S. 2005. Ozone uptake by an evergreen Mediterranean forest (Quercus ilex) in Italy. Part I: Micrometeorological flux measurements and flux partitioning. Atmospheric Environment, 39:3255-3266.

Goumenaki E., Fernandez I.G., Papanikolaou A., Papadopoulou D., Askianakis C., Kouvarakis G., Barnes J. 2007. Derivation of ozone flux-yield relationships for lettuce: A key horticultural crop. Environmental Pollution, 146:699-706.

Grulke N.E., Paoletti E., Heath R.L. 2007. Comparison of calculated and measured foliar $\mathrm{O}_{3}$ flux in crop and forest species. Environmental Pollution, 146:640-647.

Grünhage L., Haenel H.-D. 1997. PLATIN (PLant-ATmosphere INteraction) I: a model of plant-atmosphere interaction for estimating absorbed doses of gaseous air pollutants. Environmental Pollution, 98:37-50.

Grünhage L., Haenel H.-D. 2008. PLATIN (PLant-ATmosphere INteraction) - a flux estimation programme for latent and sensible heat, trace gases and aerosol constituents, in preparation.

Grünhage L., Haenel H.-D., Jäger H.-J. 2000. The exchange of ozone between vegetation and atmosphere: micrometeorological measurement techniques and models. Environmental Pollution, 109:373-392.

Grünhage L., Jäger H.-J. 1994a. Atmospheric ozone exposure-potential for vegetation: how suitable are critical levels? In: Fuhrer J., Achermann B. (eds.): Critical Levels for Ozone - a UN-ECE workshop report, 222-230. FAC Schriftenreihe (Eidgenössische Forschungsanstalt für Agrikulturchemie und Umwelthygiene, Bern), 16.

Grünhage L., Jäger H.-J. 1994b. Influence of the atmospheric conductivity on the ozone exposure of plants under ambient conditions: considerations for establishing ozone standards to protect vegetation. Environmental Pollution, 85:125-129. 
Grünhage L., Jäger H.-J. 1996. Critical levels for ozone, ozone exposure potentials of the atmosphere or critical absorbed doses for ozone: a general discussion. In: Kärenlampi L., Skärby L. (eds.): Critical levels for ozone in Europe: testing and finalizing the concepts. UN-ECE workshop report, 151-168. University of Kuopio, Department of Ecology and Environmental Science, Kuopio (FIN).

Grünhage L., Krupa S.V., Legge A.H., Jäger H.-J. 2004. Ambient flux-based critical values of ozone for protecting vegetation: differing spatial scales and uncertainties in risk assessment. Atmospheric Environment, 38:2433-2437.

Haenel H.-D., Grünhage L. 1999. Footprint analysis: A closed analytical solution based on height-dependent profiles of wind speed and eddy viscosity. BoundaryLayer Meteorology, 93:395-409.

Havranek W.M., Wieser G. 1994. Design and testing of twig chambers for ozone fumigation and gas exchange measurements in mature trees. Proceedings of the Royal Society of Edinburgh, Section B, 102:541546.

Hayes F., Mills G., Harmens H., Norris D. 2007. Evidence of widespread ozone damage to vegetation in Europe. ICP Vegetation Programme Coordination Centre, Centre for Ecology \& Hydrology, Bangor (UK).

Jarvis P.G. 1976. The interpretation of the variations in leaf water potential and stomatal conductance found in canopies in the field. Philosophical Transactions Royal Society London, Section B, 273:593-610.

Kärenlampi L., Skärby, L. 1996. Critical levels for ozone in Europe: testing and finalizing the concepts. UNECE workshop report. University of Kuopio, Department of Ecology and Environmental Science, Kuopio (FIN).

Karlsson P.E., Selldén G., Pleijel H. 2003. Establishing Ozone Critical Levels II. UNECE Workshop Report. IVL report B 1523. IVL Swedish Environmental Research Institute, Gothenburg, Sweden.

Kulmala M., Hienola J., Pirjola L., Vesala T., Shimmo M., Altimir N., Hari P. 1999. A model for $\mathrm{NO}_{\mathrm{x}}-\mathrm{O}_{3}$-terpene chemistry in chamber measurements of plant gas exchange. Atmospheric Environment, 33:2145-2156.

Laisk A., Kull O., Moldau H. 1989. Ozone concentration in leaf intercellular air spaces is close to zero. Plant Physiology, 90:1163-1167.

Lee X., Massman W., Law B. 2004. Handbook of micrometeorology. A guide for surface flux measurement and analysis. Kluwer, Dordrecht.

Liu H., Peters G., Foken T. 2001. New equations for sonic temperature variance and buoyancy heat flux with an omnidirectional sonic anemometer. BoundaryLayer Meteorology, 100:459-468.

Marenco A., Gouget H., Nédélec P., Pagés J.-P., Karcher F. 1994. Evidence of a long-term increase in tropospheric ozone from Pic du Midi data series: Consequences: Positive radiative forcing. Journal of Geophysical Research, 99:16617-16632.
Massman W.J. 1998. A review of the molecular diffusivities of $\mathrm{H}_{2} \mathrm{O}, \mathrm{CO}_{2}, \mathrm{CH}_{4}, \mathrm{CO}, \mathrm{O}_{3}, \mathrm{SO}_{2}, \mathrm{NH}_{3}, \mathrm{~N}_{2} \mathrm{O}, \mathrm{NO}$, and $\mathrm{NO}_{2}$ in air, $\mathrm{O}_{2}$ and $\mathrm{N}_{2}$ near STP. Atmospheric Environment, 32:1111-1127.

Massman W.J., Musselman R.C., Lefohn A.S. 2000. A conceptual ozone dose-response model to develop a standard to protect vegetation. Atmospheric Environment, 34:745-759.

McNaughton K.G., van den Hurk B.J.J.M. 1995. A "Lagrangian" revision of the resistors in the two-layer model for calculating the energy budget of a plant canopy. Boundary-Layer Meteorology, 74:261-288.

Midgley P., Builtjes P., Fowler D., Harrison R., Hewitt N., Moussiopoulos N., Noone K., Tørseth K., VolzThomas A. 2003. Towards cleaner air for Europe science, tools and application. Part 1. Results from the EUROTRAC-2 synthesis and integration project. Margraf Publishers, Weikersheim.

Mikkelsen T.N., Ro-Poulsen H., Pilegaard K., Hovmand M.F., Jensen N.O., Christensen C.S., Hummelshoej P. 2000. Ozone uptake by an evergreen forest canopy: temporal variation and possible mechanisms. Environmental Pollution, 109:423-429.

Mikkelsen T.N., Ro-Poulsen H., Hovmand M.F., Jensen N.O., Pilegaard K., Egeløv A.H. 2004. Five-year measurements of ozone fluxes to a Danish Norway spruce canopy. Atmospheric Environment, 38:2361-2371.

Paoletti E., Manning W.J. 2007. Toward a biologically significant and usable standard for ozone that will also protect plants. Environmental Pollution, 150:85-95.

Pieterse G., Bleeker A., Vermeulen A.T., Wu Y., Erisman J.W. 2007. High resolution modelling of atmospherecanopy exchange of acidifying and eutrophying components and carbon dioxide for European forests. Tellus, 59B:412-424.

Schönbein C.F. 1844. Über die Erzeugung des Ozons auf chemischem Wege. Schweighauser'sche Buchhandlung, Basel.

Schuepp P.H. 1993. Leaf boundary layers. Tansley Review No. 59. New Phytologist, 125:477-507.

Schuepp P.H., Leclerc M.Y., MacPherson J.I., Desjardins R.L. 1990. Footprint prediction of scalar fluxes from analytical solutions of the diffusion equation. Boundary-Layer Meteorology, 50:355-373.

Stewart J.B. 1988. Modelling surface conductance of pine forest. Agricultural and Forest Meteorology, 43:19-35.

Swinbank W.C. 1951. The measurement of vertical transfer of heat and water vapor by eddies in the lower atmosphere. Journal of Meteorology, 8:135-145.

Tausz M., Grulke N.E., Wieser G. 2007. Defense and avoidance of ozone under global change. Environmental Pollution, 147:525-531.

Thomas C., Foken T. 2002. Re-evaluation of integral turbulence characteristics and their parameterisations. In: 15th Conference on Boundary Layer and Turbulence, 15-19 July 2002, Wageningen (NL), 129-132. American Meteorological Society, Boston. 
Tingey D.T., Andersen C.P. 1991. The physiological basis of differential plant sensitivity to changes in atmospheric quality. In: Taylor G.E., Pitelka L.F., Clegg M.T. (eds.): Ecological genetics and air pollution, 209235. Springer, New York.

Tingey D.T., Taylor G.E. 1982. Variation in plant response to ozone: A conceptual model of physiological events. In: Unsworth M.H., Ormrod D.P. (eds.): Effects of gaseous air pollution in agriculture and horticulture, 113-138. Butterworth Scientific, London,

UNECE 1988. ECE critical levels workshop report. Bad Harzburg, Germany, 14-18 March 1988. Final draft report. United Nations - Economic Commission for Europe.

UNECE 1999. Protocol to the 1979 Convention on Long-Range Transboundary Air Pollution to Abate Acidification, Eutrophication and Ground-Level Ozone. Gothenburg, thirthieth day of November.

UNECE 2007. Mapping Manual 2004. Manual on methodologies and criteria for medelling and mapping critical loads \& levels and air pollution effects, risks and trends. 2007 revision. Available from www.icpmapping.org.

Vingarzan R. 2004. A review of surface ozone background levels and trends. Atmospheric Environment, 38:3431-3442.

Wang D., Hinckley M., Cumming A.B., Braatne J. 1995. A comparison of measured and modeled ozone up- take into plant leaves. Environmental Pollution, 89:247-254

Webb E.K., Pearman G.I., Leuning R. 1980. Correction of flux measurements for density effects due to heat and water vapour transfer. Quarterly Journal of the Royal Meteorological Society, 106:85-100.

Wieser G., Luis V.C., Cuevas E. 2006. Quantification of ozone uptake at the stand level in a Pinus canariensis forest in Tenerife, Canary Islands: An approach based on sap flow measurements. Environmental Pollution, 140:383-386.

Wieser G., Tausz M. 2006. Proceedings on the workshop "Critical Levels of Ozone: Further Applying and Developing the Flux-based Concept". Obergurgl, Tyrol, Austria, 15-19 November 2005. Federal Research and Training Centre for Forests, Natural Hazards and Landscape (BFW), Vienna, Austria.

Wieser G., Tausz M., Wonisch A., Havranek W.M. 2001. Free radical scavengers and photosynthetic pigments in Pinus cembra L. needles as affected by ozone exposure. Biologia Plantarum, 44:225-232.

Wilczak J.M., Oncley S.P., Stage S.A. 2001. Sonic anemometer tilt correction algorithms. BoundaryLayer Meteorology, 99:127-150.

Zhang L., Brook J.R., Vet R. 2002. On ozone dry deposition - with emphasis on non-stomatal uptake and wet canopies. Atmospheric Environment, 36:47874799 . 